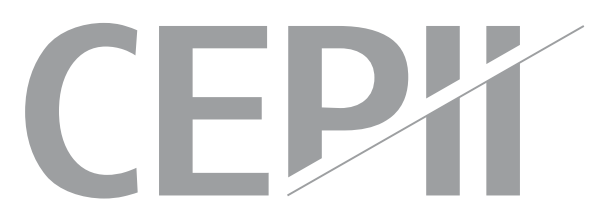

\title{
Capital Inflows, Exchange Rate Regimes and Credit Dynamics in Emerging Market Economies
}

Robin Boudias

\section{Highlights}

- We estimate a Panel Smooth Transition Regression (PSTR) model in order to assess whether the impact of exchange rate regime (ERR) on credit dynamics is affected by the cyclical component of capital flows.

- ERR has no impact on the cyclical component of capital flows.

- Credit expansion is procyclical in economies with pegged curencies.

- Countries with pegged currencies experience a higher level of dollarization, but only during capital inflows or low outflows periods. 


\section{Abstract}

This paper investigates the impact of the exchange rate regime (ERR) on the cycle of capital flows, the private credit growth rate and the level of dollarization in emerging market economies. We consider two different panels including 12 and 22 countries over the periods 1980-2010 and 1994-2008, respectively. We estimate a Panel Smooth Transition Regression (PSTR) model in order to assess whether the impact of ERR on credit dynamics is affected by the cyclical component of capital flows. Our findings are threefold. First, the ERR has no impact on the cyclical component of capital flows. Second, credit expansion is procyclical in economies with pegged curencies. Third, during capital inflows or low outflows periods, economies with fixed exchange rate regimes show a higher level of dollarization. When outflows are sizeable, ERR no longer impacts the level of dollarization. These results suggest that ERR should be an important variable in conceiving the policy mix to cope with domestic credit expansions and liability dollarization.

\section{Keywords}

Emerging market economies, Capital flows, Domestic credit, Dollarization, PSTR.

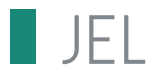

C33, E42, F31, O16.

\section{Working Paper}

\section{CEPI}

CEPII (Centre d'Etudes Prospectives et d'Informations Internationales) is a French institute dedicated to producing independent, policyoriented economic research helpful to understand the international economic environment and challenges in the areas of trade policy, competitiveness, macroeconomics, international finance and growth.
CEPII Working Paper

Contributing to research in international economics

(c) CEPII, PARIS, 2014

All rights reserved. Opinions expressed in this publication are those of the author(s) alone.

$\begin{array}{ll}\text { Editorial Director: } & \text { CEPII } \\ \text { Sébastien Jean } & \begin{array}{l}\text { 113, rue de Grenelle } \\ 75007 \text { Paris }\end{array} \\ \text { Production: } & +33153685500 \\ \text { Laure Boivin } & \text { www.cepii.fr } \\ \text { No ISSN: } 1293-2574 & \text { Press contact: presse@ }\end{array}$




\title{
Capital Inflows, Exchange Rate Regimes and Credit Dynamics in Emerging Market Economies ${ }^{1}$
}

\author{
Robin Boudias*
}

\section{Introduction}

Emerging market economies (EMEs) consist in a heterogenous group of countries identified as economies with intermediate per capita GDP ratios and engaged in a catching-up process with advanced economies. These economies have initiated important structural reforms from the late 1980s such as financial account liberalization, fiscal imbalances reduction and desinflation programs in order to gain access to international capital markets. International financial integration of EMEs as well as higher rates of return in these economies have led international banks and investors to look for borrowers and portfolio opportunities in EMEs, especially since the early 1990s (Committee on the Global Financial System, 2009). Moreover, a surprising consequence of globalization has been a decrease in the business cycle correlation between advanced and emerging economies, then fostering diversification strategies from investors. ${ }^{2}$

From the perspective of recipient countries, foreign borrowing can finance investment and foster economic growth, as well as increase welfare by facilitating consumption smoothing (Bekaert et al., 2005). However, capital flows to EMEs appear to be unstable and volatile, subject to over-shootings and brutal reversals (Agosin and Huaita, 2010). More precisely, they are at least partially driven by global factors, on which EMEs have no control (Ghosh et al., 2014).

Since the early 1990s, as capital flows to EMEs became significant, a very extensive literature has paid attention to the macroeconomic consequences they may induce on recipient economies. Without listing them all, the main concerning issues have been inflationary pressures and real exchange rate appreciation (Calvo et al., 1994), the procyclicality of capital flows with business cycle (Kaminsky et al., 2011; Reinhart and Reinhart, 2008) and the impact of capital flows on asset prices (Calvo, 2011).

In this paper, however, we pay special attention to the nexus between capital flows,

\footnotetext{
${ }^{1}$ The views expressed in this paper are those of the authors and do not necessarily reflect those of the Institutions to which they belong. The author is very grateful to Jean-Pierre Allegret, Valérie Mignon, Sébastien Jean and Natacha Valla for their comments.

${ }^{*}$ CEPII, (robin.boudias@gmail.com)

${ }^{2}$ This decrease in business cycle correlation is called "decoupling" by Kose and Prasad (2010).
} 
domestic credit growth rate and liability dollarization. ${ }^{3}$ As argued by the Committee on the Global Financial System (2009), increased financial integration and strengthening of domestic banking systems in EMEs may have been at the core of a rapid credit growth in these economies during the last few years. Basically, banks can finance domestic credit either through domestic deposits or borrowing in domestic and external markets. The CGFS (2009) shows that banks in EMEs have experienced increasing loan-to-deposit ratios since the early 2000s, which induce a higher reliance on external funding for credit issuance. $^{4}$

While (excessive) credit growth may induce a deterioration in banks asset quality, at least two consequences may emerge when the latter is mainly financed with foreign liabilities. On the one hand, the rise in loan-to-deposit ratio may decrease balance sheet liquidity and cause more important deterioration when the cycle reverses. On the other hand, banks are most likely to seek for foreign currency lending as foreign capital flows increase. ${ }^{5}$ This situation may cause an "indirect currency mismatch" 6 for banks, especially concerning loans to households and small and medium-sized enterprises as argued by the CGFS (2009).

The conventional framework to analyze this question is the impossible trinity principle. ${ }^{7}$ Capital inflows in an economy with a floating exchange rate regime ERR (ERR hereafter) would appreciate the currency without any other nominal impact. At the opposite, during large capital inflows periods, non-sterilized interventions on the foreign exchange market may increase the monetary base in economies with more rigid ERR. Moreover, an increase in interest rates may foster larger capital inflows, exerting upward pressures on the exchange rate. Consequently, economies with less flexible exchange rate regimes may be more likely to experience a higher credit expansion in the presence of large capital inflows. ${ }^{8}$

Concerning the currency composition of domestic credit, two mechanisms may combine, explaining a higher level of foreign currency denominated debt in countries with a credible fixed regime as emphasised by Tirpák and Rosenberg (2008) in the case of the new

\footnotetext{
${ }^{3}$ Thereafter, we will refer to domestic credit growth rate and liability dollarization as credit dynamics. ${ }^{4}$ Especially in Emerging Europe defined as Central Europe (the Czech Republic, Hungary and Poland), the Baltic states (Estonia, Latvia and Lithuania), Southeastern Europe (Bulgaria, Croatia, Romania and Turkey) and two CIS states (Russia and Kazakhstan).

${ }^{5}$ Therefore, it is not a higher level of foreign liabilities that causes a raise in credit growth, but more capital flows providing easy refinancing conditions for domestic banks.

${ }^{6}$ The banks being exposed to currency depreciation through the indirect channel of the lower credit quality of borrowers with currency mismatches.

${ }^{7} \mathrm{~A}$ quite extensive survey on that matter is provided in (1999).

${ }^{8}$ Mendoza and Terrones (2008), for instance, show that $73.91 \%$ of credit booms identified in their dataset occur in countries with fixed and managed exchange rate regimes. But this particular issue has been mainly overlooked by previous studies.
} 
member states of the European Union. On the one hand, domestic borrowers ${ }^{9}$ may prefer foreign currency loans not only because (i) nominal international interest rates are lower than domestic interest rates, but also because (ii) when making a decision to borrow, domestic borrowers will often use expected domestic inflation or wage growth to deflate the nominal foreign currency interest rate. On the other hand, external funding by domestic banks in international markets may be easier when the refinancing instrument are denominated in foreign currency. This is particularly true when large capital inflows seeking for higher rates of return are fueling the credit expansion and make foreign currency borrowing easy. Therefore, in a country with a highly credible peg, only a small interest rate differential can induce a shift in credit composition. This may have been the case in Eastern European countries as prospects for European Union access in the early 2000s raised both the growth potential and the credibility of new members.

Our approach is particularly close to the study by Magud et al. (2011). They show that exchange rate regimes of the EMEs during large inflows episodes may have a significant impact on credit distribution and liability dollarization. ${ }^{10}$ They find that more rigid commitments tend to experience a higher level of credit-to-GDP ratio and that its composition tilts to foreign currency denominated debt. They argue that unsterilized foreign exchange intervention used to maintain the peg during -large- inflows episodes may cause an increase in monetary base, and consequently a credit expansion. However, they only focus on periods of large capital inflows. A more comprehensive approach should extend the analysis to outflows episodes and study possibly different impacts of ERR on credit dynamics. This is our aim in the present paper. To the best of our knowledge, most of the literature has overlooked the impact of ERR on domestic credit dynamics. Our paper aims at filling this gap by investigating the impact of ERR on credit dynamics. Our basic assumption is that more rigid ERR should have a procyclical impact on those credit dynamics. Reserves accumulation and higher interest rates may foster credit issuance during large inflows episodes while larger credit restrictions may follow capital outflows. The same applies for liability dollarization. In other words, we aim at documenting a non linear impact of ERR on credit dynamics with respect to capital inflows and outflows. From a methodological viewpoint, we rely on the Panel Smooth Transition Regression (PSTR) model introduced by González et al. (2005). We consider two different panels including 12 and 22 EMEs, covering the periods 1980-2010 and 1994-2008, respectively.

Three findings emerge from our empirical analysis. First, the exchange rate regime does not impact the cycle of capital flows. Therefore, the ERR effect on credit dynamics must work through a transmission channel that goes beyond the credit expansion associated with capital inflows. Second, during large cyclical outflows periods, countries which have

\footnotetext{
${ }^{9}$ When the latters consider the exchange risk to be low.

${ }^{10}$ Working on a dataset of 24 emerging economies, they study the impact of the exchange rate arrangement on credit dynamics, but only during periods when capital flows are higher than their HodrickPrescott trended values.
} 
adopted more flexible regimes experience a higher credit growth rate (or a lower reduction). During normal periods (net inflows or relatively low outflows), economies with pegged and intermediate exchange rate regimes experience a higher credit growth rate. Third, during large cyclical outflows periods, ERR has no impact on liability dollarization. However, during normal times, economies with pegged and intermediate exchange rate regimes experience a higher level of dollarization.

On the whole, our results suggest that ERR could be used as a macroprudential tool to cope with domestic credit expansions and liability dollarization. A higher level of exchange rate flexibility may help improve financial stability by avoiding procyclical behaviour in those two variables. Given the potential impact of excessive credit expansion and balance-sheet effects on dollarized economies, countries with fixed exchange rates may be more vulnerable to capital flows reversals.

The remainder of our paper is organized as follows. Section 1 presents the data. In Section 2 we display our empirical strategy and econometric framework. In Section 3, our main findings are presented and commented. The final Section concludes.

\section{Data}

We use annual data for 4 Asian economies (Indonesia, Malaysia, Philippines and Thailand), 11 emerging European countries (Bulgaria, Croatia, Czech Republic, Estonia, Hungary, Latvia, Poland, Romania, Russia, Slovak Republic and Turkey) and 7 Latin American countries (Argentina, Brazil, Chile, Colombia, Mexico, Peru and Uruguay).

Available data do not cover the same time periods for all countries. Especially, data for Eastern Europe countries do not exist before 1993. We thus build two different panels spanning different periods. Panel 1 includes all Asian and Latin American countries plus Turkey over the period 1980-2010. Panel 2 includes Panel 1 plus all remaining Eastern Europe countries over the period 1994-2008.

Table .1 in Appendix provides all definitions and sources of the variables used throughout our empirical analysis. Regarding the exchange rate regime (ERR), we use the Reinhart and Rogoff (2004) de facto exchange rate regime (coarse) classification updated by Ilzetski, Reinhart and Rogoff (2008). ${ }^{11}$ De facto classifications are very useful to draw a distinction between words and deeds. For instance, Reinhart and Rogoff (2004) estimate that during the post Bretton-Wood period, about 53 percent of de jure "managed float" regimes were de facto experiencing a peg or crawling peg. As in Levy-Yeyati and Sturzenegger (2005), the coarse index uses several indicators to determine the effective

\footnotetext{
${ }^{11}$ This classification scores from 1 to 6 , an increase in the index corresponding to a more flexible ERR as detailed in Table 1.
} 
ERR practices instead of relying on de jure arrangements declared by countries to the IMF. These indicators are mostly based on the exchange rate volatility as well as international reserves hold by the Central Bank. The lower the exchange rate volatility and the higher the international reserves volatility, the more fixed the exchange rate regime will be considered. Reinhart and Rogoff (2004) also improve Levy-Yeyati and Sturzenegger (2005) methodology by taking into account the existence of nonunified exchange rate markets (multiple exchange rates and parallel markets), which have concerned up to 20 percent of the EMEs during the 1990s.

\section{Table 1 - Exchange Rate Regimes - coarse Classification}

1 No separate legal tender

1 Pre announced peg or currency board arrangement

1 Pre announced horizontal band that is narrower than or equal to $\pm 2 \%$

1 De facto peg

2 Pre announced crawling peg

2 Pre announced crawling band that is narrower than or equal to $\pm 2 \%$

2 De factor crawling peg

2 De facto crawling band that is narrower than or equal to $\pm 2 \%$

3 Pre announced crawling band that is wider than or equal to $\pm 2 \%$

3 De facto crawling band that is narrower than or equal to $\pm 5 \%$

3 Moving band that is narrower than or equal to $\pm 2 \%$ (i.e., allows for both appreciation and depreciation over time)

3 Managed floating

4 Freely floating

5 Freely falling

6 Dual market in which parallel market data is missing

For capital flows, we use capital flows to GDP net of FDI. On the one hand, it is generally assumed that FDI is more stable than portfolio investment, thus substracting FDI from capital flows allows us to focus on a more volatile component of capital flows. On the other hand, it would be of a great interest to use gross capital flows to check for the robustness of our results. But as argued by Ghosh et al. (2014), large positive gross inflows ("surges") are often associated with large positive gross outflows ("capital flight") so that net flows are low during those periods. ${ }^{12}$ Yet net flows, rather than gross flows, are key determinants of most concerning matters for EMEs such as «competitiveness, macroeconomic management, and the economy's aggregate foreign currency exposure». We believe that the same applies for credit dynamics on which we focus in the present paper.

Since we cannot obtain the data for domestic credit labelled in foreign currency, we follow Levy-Yeyati et al. (2010) and use the Foreign Liabilities to Money ratio (FLM) as a proxy for dollarization. According to the literature, countries with a high level of foreign liabilities are expected to be more prone to peg their currency (Eichengreen and

${ }^{12}$ The same applies when negative gross inflows ("sudden stop") are offset by negative gross outflows ("retrenchment"). 
Haussman, 1999).

The variable labeled kaopen is a financial account openness indicator proposed by Chinn and Ito (2008) and is based on the restriction on cross-border financial transactions reported in the IMF's Annual Report on Exchange Arrangements and Exchange Restrictions (AREAER). To control for the crisis effect, we use Laeven and Valencia (2008, 2010 and 2012) systemic banking, currency and sovereign debt crisis database.

We perfom various first and second generation panel unit root tests in order to assess the order of integration of our series, ${ }^{13}$ evidencing that our variables are stationary. ${ }^{14}$

\section{Empirical Strategy}

\subsection{Identifying Cyclical Capital Flows}

\subsubsection{Methodology}

To investigate whether cyclical capital flows impact the links between ERR and credit dynamics, we first add for each region (Asia, Eastern Europe, and Latin America) and for each year the ratio of non FDI net capital flows to GDP. We thus obtain total regional flows, meaning that capital flows take the same values for each country belonging to the same region. It allows us to take into account the spillover effects that could exist between different countries in the same area. Indeed, (i) these countries are most likely to be trading partners, therefore making possible contagion through the commercial account channel, and (ii) foreign investors may lack country-specific informations and let their investment decisions to be driven by regional developments rather than fundamentals increasing contagion effects. ${ }^{15}$

We then de-trend these series using a standard Hodrick-Prescott filter. As we use annual data, we follow Ravn and Uhlig (2002) and set the value of the smoothing parameter at 6.25. We finally obtain the cyclical components by substracting the HP-trended value from total capital flows. ${ }^{16}$ They correspond to the short run dynamics of the financial account we pay interest to. Indeed, it is of interest to focus on the cyclical component of capital flows instead of raw data because short run dynamics may drive most of the relationships we study. For instance, during a period of sharp decrease of net capital flows, even though they would remain positive, the cyclical component could be negative, suggesting that the region has severe financial account issues and may experience this sharp decrease in the inflows as a net outflow.

\footnotetext{
${ }^{13}$ Results are available upon request to the author.

${ }^{14}$ Excepted for the kaopen variable which is considered in first difference.

${ }^{15}$ For instance, Ghosh et al (2014) show that regional contagion increases the probability of liabilitydriven surges.

${ }^{16} \mathrm{HP}_{- \text {cycle }_{j, t}=\text { TotalCapitalFlows }_{j, t}-H P-\text { trended }_{j, t} \text {, for each region } j, j=1,2,3}$
} 


\subsubsection{Key Features}

The first wave occurred in the mid-70s following the oil shocks. Indeed, oil producing countries' surpluses have been channeled into international banks that recycled them toward developing countries as international lending in dollars. As a result, recipient econonomies had to suffer from high indebtedness and currency mismatches that led to the debt crisis of the early 1980s which mostly concerned Latin American countries. The latter was marked by a sharp decrease in "nonportfolio net private flows" in EMEs (Bacchetta and Van Wincoop, 2000). During the late 1980s and early 1990s, in the aftermath of the resolution of the international debt crisis, portfolio started to flow from advanced to emerging economies. This second wave is in part the consequence of the low international interest rates environment that prevails at this time, and also the result of a diversification strategy adopted by international investors. Indeed, emerging economies present a higher risk degree but also a higher rate of return than developed economies. In addition, rates of return in emerging countries tend to be few connected with those in advanced ones. At the same time, EMEs conducted structural reforms such as openning their financial accounts and liberalizing their domestic financial systems in order to gain access to international capital and finance their development. Since the early 2000s, international capital flows have been subject to an increasing volatility. ${ }^{17}$ This is particularly true for EMEs where cycles in capital inflows seem to be growing both in pace and intensity. In advanced economies, gross inflows tend to be largely offset by gross outflows (generating smaller variations in net flows). This is not the case for EMEs toward which net capital flows reached unprecedented levels in the pre-crisis period. ${ }^{18}$ This bonanza ${ }^{19}$ was followed by a very sharp drop during the 2007 turmoil and a bounce back in 2008 and 2009. Indeed, the net private flows to EMEs reached nearly the same level in 2010 as in 2007 . More recently, anticipations toward a possible monetary policy tightening in advanced economies led to relatively large outflows from EMEs.

These different waves of capital inflows suggest that emerging countries have experienced periods of large capital inflows which eventually took the form of overshootings, unfortunately associated with crisis periods. Figure 1 reflects changes in international capital flows to emerging countries. More specifically, it depicts total observed capital flows and trends (left panel) and cyclical component (right panel) for our three regions. For Asia, we identify large inflows in the 1980s and the early 1990s (over 20\% of GDP), brutally interrupted during the 1997 crisis, and followed by a slow recovery over the 2000s. For Latin America, we observe a sharp decrease in net flows in the early 1980s due to the debt crisis. The bonanza in the 1990s lasts longer than in Asia and continues until 2002 and the Argentina crisis which created a sharp decrease in capital inflows to the whole area. For Europe, capital inflows are near zero before the mid-1990s, then increase rapidly as these countries integrate EU. For the three considered regions, we

\footnotetext{
${ }^{17}$ Figure .1 in Appendix depicts the evolution of net private capital flows to EMEs and developing countries as defined by the IMF from 1980.

${ }^{18}$ Up to 691.02 billions USD in 2007.

${ }^{19}$ Defined as a large and persistent capital inflows period by country-specific historical standards (Reinhart and Reinhart, 2008).
} 
observe a significant rebound of inflows after the 2007 crisis, whereas Eastern Europe might have suffered from the freezing of the interbank lending market in Europe from 2007 causing a marked decrease in the inflows destinated to this area.

During the most recent period, two major determinants seem to have underpinned capital flows toward EMEs. On the one hand, their resilience during the crisis episodes has become more important than in the past. For instance, the Committee on the Global Financial System points out in a 2009 publication that the average growth rate as well as the ratio of saving to GDP and the fiscal balance in EMEs and developing countries were higher during 1993-96 than 2004-07 (two periods of large inflows in these economies). This may help these economies to strenghten themselves in such "good periods" and become more resilient when the cycle reverses. In particular, Kaminsky et al. (2005) underline that capital inflows and fiscal policies in EMEs tend to be procyclical over the period 1960-2003 (expansionary policies associated with inflows in good times and contractionary policies associated with outflows in bad times) and thus may worsen the impact of crisis. From this viewpoint, fiscal surpluses recorded in EMEs during the latest inflows period may indicate an improvement in capital flows management and fiscal policies in those countries toward more countercyclical policies. On the other hand, quantitative easing policies in investors countries seem to have influenced capital flows to the EMEs. As a result, they experienced periods of large capital inflows which eventually took the form of overshootings, unfortunately associated with crisis periods. 
Figure 1 - Defining Regional Capital Flow Cycles
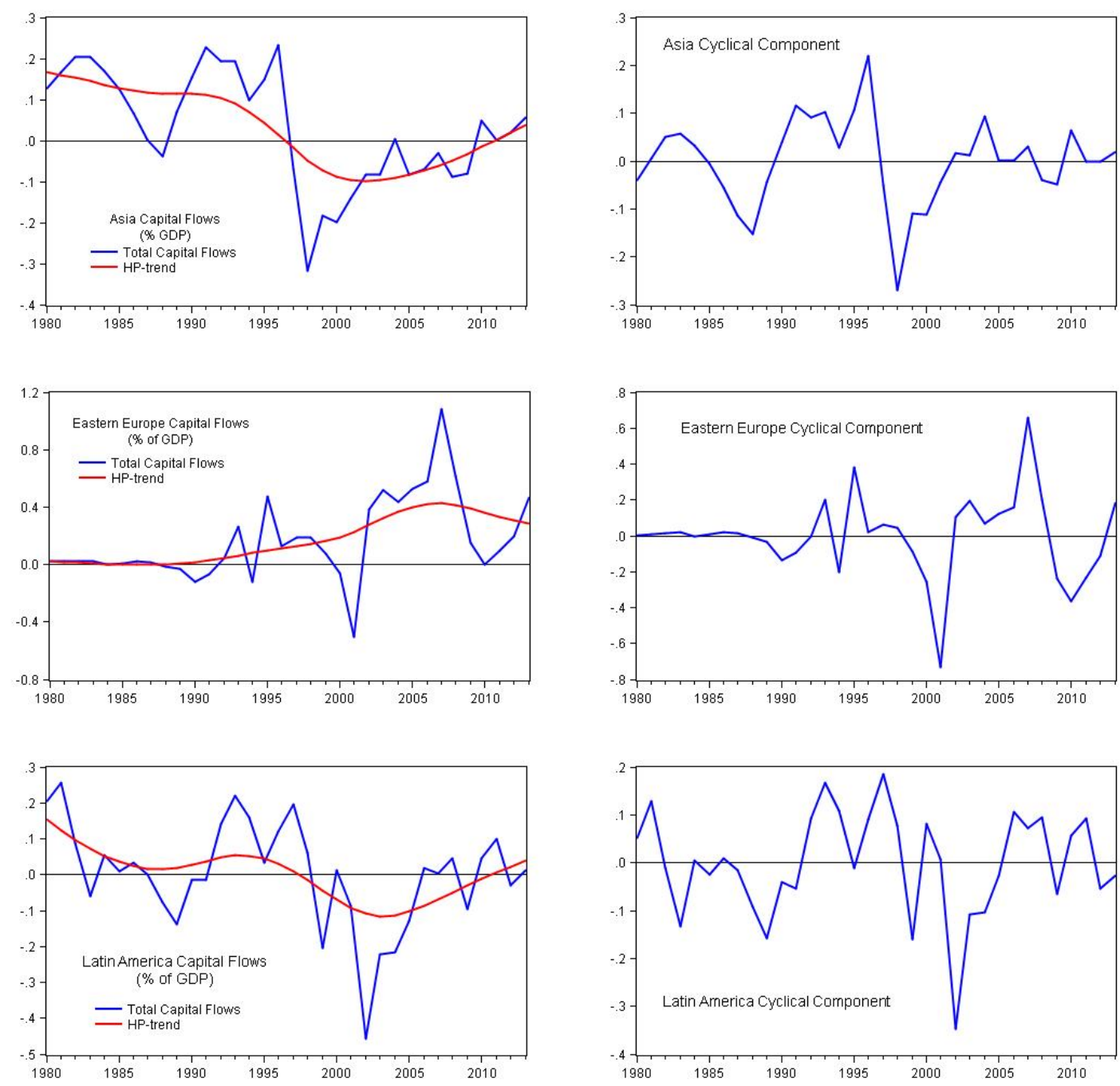

Source : Author's calculations. See Table .1 for data sources

\subsection{Econometric Framework}

\subsubsection{Capital Flows and the Exchange Rate Regime}

Does ERR impact the volume of capital flows? More specifically, the relationship between ERR and credit dynamics ${ }^{20}$ may be due to the fact that economies with different degrees of exchange rate flexibility receive different amounts of capital inflows. In order to check this hypothesis, we estimate linear panel regressions for both Panel 1 and Panel 2 using the following specification estimated through OLS:

$$
k \_ \text {cyclecomp } p_{i, t}=\eta+\beta^{\prime} E R R_{i, t}+\kappa^{\prime} M_{i, t}+\nu^{\prime} C_{i, t}+\gamma^{\prime} E R R_{i, t} \times C_{i, t}+\varepsilon_{i, t}
$$

${ }^{20}$ Defined as either the growth rate of private credit issued by banking sector or the FLM index. 
Where $k \_$cyclecomp $p_{i, t}$ is the cyclical component of capital flows to country $i$ 's region at year $t . E R R_{i, t}$ is the de facto exchange rate regime of country $i$ at time $t, M_{i, t}$ is the matrix for macroeconomic and financial control variables such as financial and trade openness, international interest rates, short-term interest rate differentials and GDP growth rate. $C_{i, t}$ denotes the vector for crisis dummies and $\varepsilon_{i, t}$ is the error term.

As robustness checks, we (i) include fixed and time effects and (ii) use the Generalized Least Squares (GLS) estimator, accounting for both heteroskedasticity and autocorrelation in the residuals. The model thus becomes:

$$
k_{\_} \text {cyclecomp }_{i, t}=\phi^{\prime} f_{i / t}+\beta^{\prime} E R R_{i, t}+\kappa^{\prime} M_{i, t}+\nu^{\prime} C_{i, t}+\gamma^{\prime} E R R_{i, t} \times C_{i, t}+\varepsilon_{i, t}
$$

Where $\phi^{\prime} f_{i / t}$ stands for fixed and time effects.

\subsubsection{Exchange Rate Regime and Credit Dynamics}

We then pay attention to the relation between ERR and credit dynamics in the two panels. Our basic assumption is that this nexus might be different with respect to whether capital flows are pouring in or fleeing a country/region. For instance, if we suppose that more pegged economies are prone to experience a higher degree of dollarization, this relation may be even stronger when capitals outflow these countries. Indeed, a higher risk of devaluation induced by net outflows may deter foreign lenders/investors from local currencies. In other words, the exchange rate arrangement would have a nonlinear impact on the FLM index depending on the cyclical component of capital flows. We propose to check this hypothesis, using a PSTR model. ${ }^{21}$ This specification proposed by González, Terasvirta and Dijk (2005) is a model with individual fixed effects where the effect of the exogenous variables on the endogenous variable depends on a logistic transition function, normalized and bounded between 0 and 1 . The basic PSTR model can be written as follows:

$$
y_{i, t}=\mu_{i}+\beta_{0}^{\prime} x_{i, t}+\beta_{1}^{\prime} x_{i, t} g\left(q_{i, t} ; \gamma, c\right)+u_{i, t}
$$

Where the dependent variable $y_{i, t}$ is a scalar (successively the growth rate of the domestic credit and the FLM index), $x_{i, t}$ is a k-dimensional vector of time-varying exogenous variables, $\mu_{i}$ denotes individual fixed effects and $u_{i, t}$ are the errors.

\footnotetext{
${ }^{21}$ All the PSTR estimations are performed on the RATS software using GTVD.SRC, a program provided by Gilbert Colletaz whom we are grateful for having made it available on: http://www . univ-orleans . $\mathrm{fr} / \mathrm{deg} / \mathrm{masters} / \mathrm{ESA} / \mathrm{GC} / \mathrm{gcolletaz} R$.htm
} 
The transition function $g\left(q_{i, t} ; \gamma, c\right)$ is a continous function of the observable transition variable $q_{i, t}$, taking a logistic form:

$$
g\left(q_{i, t} ; \gamma, c\right)=\left[1+\exp \left(-\gamma\left(q_{i, t}-c\right)\right)\right]^{-1}
$$

Whether the threshold variable is higher or lower than the threshold $c$ determines the value of $g\left(q_{i, t} ; \gamma, c\right), \gamma$ being the speed of transition between the two extreme regimes. Thus the effect of the exogenous variables on the dependent variable is equal to $\beta_{0}+$ $\beta_{1} g\left(q_{i, t} ; \gamma, c\right)$ and depends on the transition variable, namely, the cyclical component of net capital flows to the region where the $i^{\text {th }}$ country belongs. ${ }^{22}$

\section{Main Findings}

We first test whether the ERR impacts the cyclical component of capital flows. We then study the impact of ERR on credit dynamics, discriminating between capital inflows and outflows periods.

\subsection{ERR does not impact capital flows}

As explained in the previous section, our first objective is to determine whether the exchange rate policy impacts the cycle of capital inflows. This is a key question since it may explain later why countries with different exchange rate arrangements experience different credit dynamics. Indeed, if countries with more rigid exchange rate regimes attract more capital inflows, then those inflows could be used to develop credit (for instance through banking intermediation), and credit financed with foreign capital would raise the FLM ratio. Thus, there would be no surprise to observe a higher degree of foreign liabilities to money ratio in countries with pegged currency (especially during "good" periods) if those countries attracted more capital inflows. Magud et al. (2011) point three reasons why pegged economies may attract higher capital inflows. First, «by reducing nominal exchange rate volatility-compared to flexible regimes-pegs can reduce transaction costs, encouraging cross-border investment». Nominal exchange rate stability may lower the risk incurred by foreign investors and thus attract higher inflows. Second, pegged nominal exchange rates may induce investors to "take advantage of even small interest rate differentialsı. Finally, during periods of high capital inflows, sterilized interventions used to maintain the nominal exchange rate without spurring inflation can help to maintain real interest rates in pegged economies and induce larger capital inflows.

The first conclusion we get from our OLS estimations reported in Table .3 is that the exchange rate regime never impacts the cyclical component of capital inflows, regardless

${ }^{22}$ Calculated according to the methodology described in Section 2.1.1. 
the chosen panel or the estimation routine. ${ }^{23}$ Indeed, the estimated models display very small adjusted R-squared values, and the control variables are mostly not statistically significant. Moreover, results are very sensitive to the retained specification so that adding a variable or a lagged variable create a different output in most cases. The same is true for alternative specifications, including time and fixed effects as well as GLS estimations (Table .4). Moreover, the possible endogeneity between ERR and capital flows is a clear issue. Indeed, large outflows and sudden stop episodes may cause the abandonment of a peg or a crawling peg. In other words, capital flows are most likely to impact the ERR variable.

While other explanatory variables such as capital control measures should also play an important role (Taylor and Sarno, 1997; Ghosh et al., 2014), our findings suggest that the cyclical component of capital flows seems to be driven for a large part by the output growth, the external debt (especially for Panel 1 ) and international interest rates. The effect of external debt on capital flows is of particular interest. On the one hand, a high degree of external debt could deter investors from the country for they could question its sustainability. ${ }^{24}$ On the other hand, it also captures previous access to capital flows and may be associated with facilitated new foreign investments. These two opposing effects are likely to take different importance across various specifications and may explain the external debt sign sensitivity. Concerning output growth, the sign is always positive as expected. A higher growth prospect is very likely to drag more foreign capital to a particular country. However, the positive sign associated with international interest rate is quite puzzling since we generally observe that capitals tend to flee from EMEs to advanced economies when international interest rates are high. Crisis dummies always have a negative impact on capital flows and are more significant in Panel 2 than in Panel 1.

On the whole, our results evidence that ERR have no impact on capital flows. This result is consistent with Magud et al. (2011) who focalised on large inflows periods for a comparable set of countries. Ghosh et al. (2014) however find that pegged exchange rate countries experience 3 percent of GDP larger capital flows during surge periods than more flexible ones. This result is not conflicting with our own since Ghosh et al. focus on surge periods while we do not. A possible interpretation would be that higher inflows in pegged countries during surges are corrected by higher outflows when the cycle reverses. In this case, the average effect of the exchange rate policy on capital inflows would be close to zero as we find in our estimations. An other possible interpretation is simply that over all factors that influence capital flows, the exchange rate arrangement only plays a marginal role.

\footnotetext{
${ }^{23}$ All results are depicted in Appendix, in Tables .3 and .4 .

24 In general, more indebted countries have a higher default risk.
} 


\subsection{The Nonlinear Impact of Exchange Rate Regime on Credit Dynamics}

To study the effect of the exchange rate regime on credit dynamics and test whether this impact is different depending on the cyclical component of capital flows, we proceed to the estimation of the PSTR model. First, we define the proper specification by testing for linearity against the PSTR alternative. If the null of linearity is not rejected, we estimate a linear panel model assuming that the effect of the exchange rate regime on the dependent variable is constant. If we reject the null hypothesis, we proceed with the PSTR estimation:

$$
y_{i, t}=\mu_{i}+\beta_{0}^{\prime} E R R_{i, t}+\beta_{1}^{\prime} E R R_{i, t} g\left(k_{\_} \text {cyclecomp }_{i, t} ; \gamma, c\right)+\kappa^{\prime} M_{i, t}+\nu^{\prime} C_{i, t}+u_{i, t}
$$

Where the dependent variable $y_{i, t}$ is a scalar (successively the growth rate of domestic credit and the FLM index), $\mu_{i}$ is the individual fixed effects and $u_{i, t}$ are the errors. ${ }^{25}$

We report the results of the tests for linearity for both credit expansion and the FLM index in Table 2. We detect a nonlinear impact of the cyclical component of capital flows on credit dynamics for 3 over 4 estimations ${ }^{26}$, at the $10 \%$ significance level.

\subsubsection{Credit expansion}

Table 2 - LM and $F$ tests for linearity (p-values)

\begin{tabular}{llcccc}
\hline & \multicolumn{4}{c}{ Dependent Variable } \\
\cline { 2 - 3 } \cline { 5 - 6 } \cline { 5 - 6 } & \multicolumn{2}{c}{ Domestic } & Credit (\% change) & & \multicolumn{2}{c}{ FLM index } \\
\cline { 2 - 3 } \cline { 5 - 6 } LM & 0.062 & Panel 2 & & Panel 1 & Panel 2 \\
F & 0.066 & 0.081 & & 0.741 & 0.039 \\
\end{tabular}

LM and $F$ are Lagrange multiplier and Fischer-type tests for linearity. Under the null hypothesis, the model is linear.

We first consider the growth rate of private domestic credit issued by banking sector as the dependent variable. The estimation results for Panel 1 are reported in Table 3. The estimated threshold is equal to $-30.5 \%$, which corresponds to extreme cyclical outflows (only $2.5 \%$ of the observations, mostly Latin American countries during Argentina crisis in 2002). Our empirical strategy appears to be effective in capturing contagion effects since outflows not only concerned Argentina but Brazil, Chile and Uruguay as well. These observations correspond to our first regime associated with $\mathrm{g}()=$.0 . In this

\footnotetext{
${ }^{25}$ Note that the transition function is only associated to the ERR variable and not to the $M_{i, t}$ matrix of control variables neither the $C_{i, t}$ crisis dummies. We therefore assume that those variables have a linear impact on credit dynamics because we want to focus on the (nonlinear) impact of the exchange rate regime on credit dynamics.

${ }^{26}$ Note that PSTR estimations for credit expansion in Panel 2 yields inconsistent results regarding the estimated threshold value. We thus only consider results from the linear model.
} 
state, the effect of the exchange rate regime on credit expansion is significant at the $5 \%$ level and equal to $\hat{\beta}_{0}=0.118$, a positive sign implying that more flexible regimes are associated with higher credit growth (or less important reductions). A 1-point increase in the exchange rate classification index (a 17 percent increase) causes a 11.8 percentage points increase from the individual average in the credit expansion (which stands at $1.51 \%$ for the whole sample). Our previous results suggest that it is not due to the fact that more flexible regimes would receive more capital flows (or suffer lower outflows) since we find no impact of the exchange rate regime on capital flows. Therefore, the impact of the ERR during such periods must work through a transmission channel that goes beyond the credit expansion associated with capital inflows (which we estimate to be statistically relevant and equal to 0.364 ). A decrease in international reserves used to defend the peg in fixed ERR is a possible cause to this phenomenon. Indeed, it corresponds to a decrease in the monetary base and may induce a higher credit restriction during crisis episodes. Another possible cause is an increase in the interest rate eventually used during those episodes to make speculation against the domestic currency more costly. Indeed, in the 7 Latin American countries included in Panel 1, the average money market rate raised from $16.98 \%$ to $24.09 \%$ between 2001 and 2002 . This may have affected credit expansion as well as a decrease in the international reserves. We believe that including international reserves may be useful for improving our model, but so far, we found a larger credit restriction in fixed exchange rate regimes during outflows periods.

Our second regime associated with $\mathrm{g}()=$.1 corresponds to "normal" periods with cyclical flows higher than $-30.5 \%$. The effect of ERR gradually increases from that point to reach $\hat{\beta}_{0}+\hat{\beta}_{1}=-0.011$. During those periods, the sign of the coefficient associated with the ERR reverses and becomes negative. A 1-point decrease in the ERR index increases credit expansion by about 1.19 percentage point: more pegged regimes tend to experience a higher credit expansion. This conclusion is in line with Magud et al. (2011). A higher credit expansion in economies with a fixed ERR during capital inflows periods can be due to unsterilized accumulation of international reserves. Sterilization can be used to offset the effect of reserves accumulation, namely an increase in the monetary base. However, it can be very costly and therefore it is often partial. Thus, fixed ERR are often associated with expanding monetary base and are more likely to experience higher credit expansion through banking intermediation.

An extensive literature suggests that economies with higher credit growth rates may suffer from larger output collapses when a crisis hits, especially when it is based on foreign borrowing. Berkmen et al. (2012) find a positive linkage between credit rate of growth prior to the 2007 crisis and output loss during the crisis. They argue that the main transmission channel may be a higher level of leverage and short debt indebtness in these countries. Moreover, they find this relation is worsened by exchange rate inflexibility with a higher growth impact in countries with pegged exchange rates. Our results are in line with Berkmen et al. (2012) since we evidence a positive (a negative) impact of ERR on credit growth during normal (large outflows) periods respectively. As they 
argue, economies with higher credit expansion may suffer from larger credit restriction during crisis. Our results suggest that ERR may play a role in this relation, and this would be consistent with higher output losses in fixed exchange rate economies during crisis episodes. This feature may be determinant for EMEs and therefore should help improving exchange rate policies when taken into account. For instance, it suggests that autorities should be concerned by high credit expansion during inflows periods (especially in pegged economies), knowing that credit is more likely to go through higher restriction when the cycle reverses. This result is consistent with Mendoza and Terrones (2008) who study the case of credit booms in developed economies and EMEs. They define credit booms as periods in which the HP-cycle component of credit per capita exceeds its long-run trend by more than a given "boom" country-specific threshold over the 1975-2005 period. Regarding the EMEs group composed by 28 countries, they find that $50 \%$ of credit booms are associated with large capital inflows (the three-year average of capital inflow before the peak of the boom ranks in the top quartile of their corresponding country group). They also show that $73.91 \%$ of credit booms occur in countries with fixed and managed exchange rate regimes. ${ }^{27}$

Table 3 - Exchange rate and Domestic Credit in Panel 1: PSTR model

\begin{tabular}{|c|c|c|}
\hline Variable & Coef. & Std error \\
\hline k_cyclecomp & $0.3640 * * *$ & 0.116 \\
\hline Crisis & 0.009 & 0.025 \\
\hline ERR & $0.118 * * *$ & 0.033 \\
\hline $\mathrm{ERR}^{*} \mathrm{~g}\left(k \_\right.$cyclecomp $\left.p_{i, t} ; \gamma, \mathrm{c}\right)$ & $-0.129 * * *$ & 0.033 \\
\hline \multicolumn{3}{|l|}{ Transition Parameters } \\
\hline$\hat{c}$ & -0.305 & \\
\hline$\hat{\gamma}$ & 13.473 & \\
\hline
\end{tabular}

Regarding Panel 2, we perform a linear estimation of the following form:

$$
\begin{aligned}
& \Delta \log d o m \_c r e d_{i, t}=C+\beta^{\prime} E R R_{i, t-1}+\alpha^{\prime} C P I \_r a t e_{i, t-1} \\
& +\lambda^{\prime} M M \text { rate }_{i, t}+\phi^{\prime} \text { Crisis }_{i, t}+\gamma^{\prime} \text { Crisis }^{*} E R R_{i, t}+\varepsilon_{i, t}
\end{aligned}
$$

Where $\Delta$ logdom_cred $d_{i, t}$ is the expansion rate of domestic credit, CPI_rate $e_{i, t-1}$ is the lagged value of inflation measured by the consumer price index rate of growth, $M M$ rate $_{i, t}$ is the money market rate, Crisis $_{i, t}$ is a dummy variable for crisis, $\varepsilon_{i, t}$ are the errors and $\mathrm{Crisis}^{*} E R R_{i, t}$ is the interaction term between ERR and crisis. Therefore, the marginal effect of ERR on capital flows is $\beta^{\prime}+\gamma^{\prime}$ Crisis $_{i, t}$ and will let us know if some degree of exchange rate flexibility allows for a different evolution of credit expansion during crisis. As in the previous section, we also run alternative specifications including fixed and time effects as well as GLS estimations. Estimation results are reported in

${ }^{27}$ As we do, they use Reinhart and Rogoff (2004) classification. Fixed and managed ERR correspond to numbers 1 and 2 in the ERR index. 
Table 4.

Results for Panel 2 tend to confirm our previous findings. The exchange rate variable has a negative impact on credit (credit grows faster in economies with a fixed exchange rate). Moreover, as $\gamma$ is always higher than $\beta$ (except in the last specification), the relation is reversed during crisis periods which means that more fixed exchange rate countries experience a lower increase (a higher decrease) in domestic credit. Crisis episodes in Panel 2 can be interpreted as large outflows periods (regime 1) in Panel 1. Indeed, during all crisis episodes in Panel 2, the average cyclical flow is equal to $-6 \%$ of GDP, while it is equal to $5 \%$ of GDP during non-crisis periods. Therefore, results for Panel 1 and Panel 2 appear to be consistent.

As explained in Lim et al. (2011), many macroprudential measures aim at containing excessive credit growth as well as foreign currency denominated borrowing during capital inflows episodes. Credit-related measures often include legal caps on a range of variables such as loan-to-value ratio, debt-to-income ratio and foreign currency lending. However, those type of measures may be difficult to implement, and could generate unintended distortions or growth reduction. In this context, our result suggest that ERR may be considered as an additional tool in the box for policy makers. More specifically, during large inflows episodes, more flexible ERR could help prevent adverse effects induced by external funded credit expansion.

To sum up, fixed ERR seems to exacerbate domestic credit cycle in EMEs. During "normal periods", defined by cyclical capital inflows or small outflows, credit rate of growth is higher in economies with a pegged exchange rate or a managed float than in more flexible ones. But during large outflows periods (or crisis episodes), the relation is reversed, and fixed ERR countries experience a lower expansion or a higher credit contraction. Moreover, we find no effect of the ERR on capital flows, and ERR has a statistically significant impact on credit expansion even when controlling for capital flows. Therefore we conclude that the relationship between ERR and credit expansion is working through a transmission channel that goes beyond capital inflows. This should be of a high interest in designing exchange rate policies in the EMEs.

\subsubsection{FLM index}

We now turn to our second dependent variable in equation (5), the FLM index used as a proxy for dollarization. Accounting for the results presented in Table 2, we first perform an estimation of the following model for Panel 1:

$$
F L M_{i, t}=C+\beta^{\prime} E R R_{i, t}+\alpha^{\prime} \operatorname{ExtDebt}_{i, t}+\phi^{\prime} \operatorname{Crisis}_{i, t}+\varepsilon_{i, t}
$$

Where ExtDebt $t_{i, t}$ stands for total (public plus private) gross external debt/GDP of 
Table 4 - Exchange rate and Domestic Credit in Panel 2: Linear Model

\begin{tabular}{lcccccc}
\hline variable & \multicolumn{3}{c}{ OLS } & & \multicolumn{2}{c}{ GLS } \\
\cline { 2 - 5 } \cline { 6 - 7 } C & $0.131^{* * *}$ & $0.0157^{* * *}$ & $0.109^{* * *}$ & & $0.068^{* * *}$ & $0.109^{* * *}$ \\
& $(0.022)$ & $(0.026)$ & $(0.021)$ & & $(0.019)$ & $(0.019)$ \\
ERR(-1) & $-0.043^{* * *}$ & $-0.049^{* * *}$ & $-0.033^{* * *}$ & & $-0.022^{* * *}$ & $-0.036^{* * *}$ \\
& $(0.008)$ & $(0.009)$ & $(0.008)$ & & $(0.007)$ & $(0.008)$ \\
Inflation(-1) & & & $-0.005^{* * *}$ & & $-0.005^{* * *}$ & $-0.005^{* * *}$ \\
& & & $(0.001)$ & & $(0.001)$ & $(0.001)$ \\
Money Market Rate & $0.001^{* *}$ & & $0.005^{* * *}$ & & $0.005^{* * *}$ & $0.005^{* * *}$ \\
& $(0.000)$ & & $(0.001)$ & & $(0.001)$ & $(0.001)$ \\
Crisis & $-0.21^{* * *}$ & $-0.0196^{* * *}$ & $-0.235^{* * *}$ & & $-0.154^{* * *}$ & -0.214 \\
& $(0.048)$ & $(0.049)$ & $(0.047)$ & $(0.035)$ & $(0.046)$ \\
ERR*Crisis & $0.059^{* * *}$ & $0.062^{* * *}$ & $0.059^{* * *}$ & & $0.036^{* * *}$ & $0.052^{* * *}$ \\
& $(0.016)$ & $(0.016)$ & $(0.016)$ & & $(0.012)$ & $(0.015)$ \\
\hline Fixed Effects & No & Yes & No & & No & No \\
Time Effects & No & No & Yes & & No & No \\
Cross-Section Weights & No & No & No & & Yes & No \\
Period Weights & No & No & No & No & Yes \\
\hline Adjusted R-squared & 0.11 & 0.12 & 0.23 & & 0.18 & 0.22 \\
Observations & 297 & 307 & 296 & 296 & 296 \\
\hline
\end{tabular}

Numbers in brackets are standard errors

$* * *, * *, *$ indicate significance at 1,5 , and 10 percent levels, respectively.

country $i$ at time $t$ and $\varepsilon_{i, t}$ are the errors. Alternative specifications include time and fixed effects as well as GLS estimations. Results are reported in Table 5 and show that, when accounting for fixed effects, ERR have a negative impact on dollarization. The more rigid the exchange rate regime, the higher the level of dollarization. Also, the crisis tends to exacerbate the level of dollarization which is more consistent with previous studies (Tirpák and Rosenberg, 2008; Magud et al., 2011).

Results for Panel 2, are reported in Table 6. The estimated threshold is equal to $17.07 \%$ which corresponds to relatively high cyclical outflows. Indeed, such episodes represent $15.9 \%$ of the observations and they are associated with the first regime, in which $g()=$.0 . In this regime, ERR does not have a statistically significant impact on FLM. Controling for the effect of crisis (about 30\% of the observations under the first regime were identified as crisis years) may have capted most of the impact of ERR on the FLM index.

The second regime associated with $g()=$.1 is the most common as it contains about $85 \%$ of the observations. In this regime, ERR becomes significant and has a negative impact on dollarization. A 1-point increase in the ERR index (a more flexible regime) causes a decrease in the FLM index by -12.72 (a 19\% decrease in the average wich stands at $67.2 \%$ for the whole sample).

As for control variables, we observe that higher cyclical inflows as well as systemic crises increase the level of dollarization in our sample. A $10 \%$ increase in the cyclical component of capital flows increases the FLM index by about 4.44 points, while the occurence of a crisis causes a 21.57 points increase. 
Table 5 - Exchange rate and FLM index (Panel 1): Linear Model

\begin{tabular}{|c|c|c|c|c|c|}
\hline variable & \multicolumn{3}{|c|}{ OLS } & \multicolumn{2}{|c|}{ GLS } \\
\hline C & $\begin{array}{c}83.995 * * * \\
(24.65)\end{array}$ & $\begin{array}{c}119.814^{* * *} \\
(17.509)\end{array}$ & $\begin{array}{c}85.434 * * * \\
(26.181)\end{array}$ & $\begin{array}{c}47.148 * * * \\
(10.337)\end{array}$ & $\begin{array}{c}41.961^{* *} \\
(17.505)\end{array}$ \\
\hline ERR & $\begin{array}{l}-9.274 \\
(7.108)\end{array}$ & $\begin{array}{c}-36.216 * * * \\
(6.168)\end{array}$ & $\begin{array}{l}-5.674 \\
(7.363)\end{array}$ & $\begin{array}{l}-3.568 \\
(2.909)\end{array}$ & $\begin{array}{l}-3.674 \\
(5.155)\end{array}$ \\
\hline External Debt & $\begin{array}{c}0.179 \\
(0.352)\end{array}$ & $\begin{array}{c}1.053 * * * \\
(0.291)\end{array}$ & $\begin{array}{c}0.039 \\
(0.386)\end{array}$ & $\begin{array}{l}0.229^{*} \\
(0.138)\end{array}$ & $\begin{array}{c}0.329 \\
(0.239)\end{array}$ \\
\hline Crisis & $\begin{array}{c}44.273 * * \\
(18.851)\end{array}$ & $\begin{array}{c}22.022 * \\
(12.662)\end{array}$ & $\begin{array}{c}24.267^{* * *} \\
(20.455)\end{array}$ & $\begin{array}{c}38.025^{* * *} \\
(6.786)\end{array}$ & $\begin{array}{c}70.346^{* * *} \\
(15.258)\end{array}$ \\
\hline Fixed Effects & No & Yes & No & No & No \\
\hline Time Effects & No & No & Yes & No & No \\
\hline Cross-Section Weights & No & No & No & Yes & No \\
\hline Period Weights & No & No & No & No & Yes \\
\hline Adjusted R-squared & 0.03 & 0.63 & 0.02 & 0.19 & 0.15 \\
\hline Observations & 179 & 179 & 179 & 179 & 179 \\
\hline
\end{tabular}

Table 6 - Exchange rate and FLM index (Panel 2): PSTR model

\begin{tabular}{lcc}
\hline Variable & Coef. & Std error \\
k_cyclecomp & $44.409 * * *$ & 16.446 \\
Crisis & $21.569 * * *$ & 7.718 \\
ERR & -2.444 & 4.330 \\
ERR $^{*} g\left(k \_\right.$cyclecomp \\
$i, t ; \gamma, c)$ & $-12.721^{* * *}$ & 4.052 \\
Transition Parameters & & \\
$\hat{c}$ & -0.171 & \\
$\hat{\gamma}$ & 33.091 & \\
\hline$* * * * * * *$ indicate significance at 1,5, and 10 percent levels, respectively.
\end{tabular}

\subsection{Accounting for the Differences between Panel 1 and Panel 2}

Why do we detect a nonlinear effect of the ERR on the FLM index in Panel 2 but not in Panel 1? Morevover, why does the ERR impact the FLM index in Panel 2 but not in Panel 1? We now aim at establishing whether those differences are due to a rise in dimension $N$ or a fall in dimension $T$ from Panel 1 to Panel 2 (Panel 2 includes 10 more countries in a 15 years shorter period).

Comparing summary statistics for Panels 1 and 2 provides useful information about the evolution of the variables we pay interest to. ${ }^{28}$ Remind that Panel 2 includes more countries, but also covers a shorter period than Panel 1 . Our intuition is that focusing on the period 1994-2008 may be determinant since many consequences of the EMEs international financial integration started to become apparent by the early nineties. For instance, the cyclical component of capital flows is twice as volatile in Panel 2 as in Panel 1 (the standard deviation rises from 0.12 to 0.23 ). We also observe a sharp increase in

\footnotetext{
${ }^{28}$ These statistics are reported in Table .2 in Appendix.
} 
the trade openness variable between the two panels which is a key feature of international integration of the EMEs. The same applies for the financial account openness indicator which comes from 0.14 in Panel 1 to 0.51 in Panel 2. In other words, considering 1994 instead of 1980 as a starting point may allow us to focus on a much more tensed period and therefore obtain more interesting results. Also, 22 percent of the observations were identified as crisis periods in Panel 1 while this is the case for only 19 percent in Panel 2, but this difference seems to be due to the inclusion of Eastern European countries that have undergone fewer crises. Indeed the mean of the crisis variable for Panel 1 remains the same when calculated over the period 1980-2010. All these features tend to show that the fall in dimension $T$ may play a key role in accounting for the differences between the two panels.

To address this issue, we build a third panel, composed from Panel 1 but spanning the same time period as Panel 2 (1994-2008). We then proceed with the PSTR model estimation procedure. We cannot reject linearity at the $10 \%$ level ( $p$-values for the LM test and the F-type test are 0.31 and 0.33 respectively). This result is the same as the one we get from Panel 1. Therefore, the nonlinearity effect we detect in Panel 2 is due to the addition of the Eastern European countries instead of the different time period it covers. Linear specification results are similar to the ones in Panel 1, confirming that the differences observed between Panel 1 and Panel 2 are due to the rise in dimension $N$ rather than the fall in dimension $T$ from one panel to another.

A possible explanation to this result is the heavy reliance of the banking system in Eastern Europe countries on external markets to finance a rapid growing domestic credit. As these countries tend to show lower loan-to-deposit ratios, one could expect a higher sensibility to capital flows when they are included in regression analysis.

\section{Conclusion}

This paper investigates the impact of exchange rate regimes (ERR) on credit dynamics in emerging countries. We show that economies with more fixed exchange rates tend to experience a higher credit expansion during normal periods, (ie during net inflows or relatively small outflows episodes). However, during large cyclical capital outflows, this relation reverses, and more pegged regime economies may suffer from higher credit restriction. While we find no significant impact of ERR on liability dollarization during large outflows periods, the level of the latter tends to be higher as the exchange rate flexibility decreases during normal periods. Moreover, we find no impact of the ERR on the cyclical component of capital flows. Therefore, these relations must work through a transmission channel that goes beyond the credit expansion associated with capital inflows.

Our analysis can be extended in several ways. First, we studied two groups of countries, 
the second one including a few more economies (namely, Eastern European countries) over a shorter time period than the first one. We need a deeper comprehension of the differences we highlighted between these two panels. To this end, the empirical analysis shall be extended to the largest set of countries and the longest time period that will be possible. This may help us accounting for the relative importance of dimensions $\mathrm{N}$ and $\mathrm{T}$ in our present study. Above all, we need more data on Eastern European countries in order to obtain robust estimations. Second, it may be of a great interest to introduce a distinction in capital flows with respect to their nature. Indeed, foreign direct investment, equity flows and banking intermediation may have different properties (mostly in terms of volatility) and thus may have a different impact on credit dynamics. Third, we should include macroprudential and response policies to the analysis since capital controls as well as changes in international reserves are most likely to play a determinant role in those relations. 


\section{References}

AGOSIN M.R. and HUAITA F., (2010): "Capital flows to emerging economies: Minsky in the tropics.", Cambridge Journal of Economics, 35(4), pp. 663-683.

BACCHETTA P. and VAN WINCCOP E., (2000): "Capital flows to emerging markets: Liberalization, overshooting and volatility", Capital flows and the emerging economies: Theory, evidence, and controversies. University of Chicago Press, pp. 61-104.

BEKAERT G., HARVEY C.R. and LUNDBLAD C., (2005): "Does financial liberalization spur growth?", Journal of financial Economics, 77(1), pp. 3-55.

BERKMEN S.P., GELOS G., RENNHACK R. et al. (2012): "The global financial crisis: Explaining cross-country differences in the output impact", Journal of International Money and Finance, 31(1), pp. 42-59.

CALVO G.A., (2011) : "On Capital Inflows, Liquidity and Bubbles." Columbia University, May. Available at www. columbia. edu/gc2286.

CALVO G.A., LEIDERMAN L. and REINHART C.M., (1994) : "The capital inflows problem: Concepts and issues.", Contemporary Economic Policy 12(3), pp. 54-66.

CAVALLARO E., MAGGI B. and MULINO M., (2011): "The macrodynamics of financial fragility within a hard peg arrangement.", Economic Modelling 28(5), pp. 2164-2173.

CHINN M.D. and ITO H., (2008): "A new measure of financial openness", Journal of Comparative Policy Analysis, 10(3), pp. 309-322.

CHOI I., (2002): "Combination Unit Root Tests for Cross-Sectionally Correlated Panels", Mimeo, Hong Kong University of Science and Technology .

Committee on the Global Financial System, (2009): "Capital flows and emerging market economies", CGFS, no.33, January.

EICHENGREEN B. and HAUSMANN R., (1999): "Exchange rates and financial fragility", NBER Working Paper, no.7418, November.

FRANKEL J.A., (1999): "No single currency regime is right for all countries or at all times.", NBER Working Paper, no.7338, September.

GHOSH A., QURESHI M.S., ZALDUENDO J. et al. (2014): "Surges", Journal of International Economics, 92(2),266-285

GONZÁLEZ A., TERASVIRTA T. and DIJK D., (2005): "Panel smooth transition regression models", SSE/EFI Working Paper Series in Economics and Finance, no.604.

ILZETZKI E.O., REINHART C.M. and ROGOFF K.S., (2008): "Exchange rate arrangements into the 21st Century: Will the anchor currency hold?", The Quarterly Journal of Economics, vol. 119, no 1 , pp. 1-48. 
KAMINSKY G.L., REINHART C.M. and VÉGH C.A., (2005): "When it rains, it pours: procyclical capital flows and macroeconomic policies" NBER Macroeconomics Annual Volume 19, MIT Press, pp. 11-82.

KOSE A., PRASAD E.S, (2010): "Emerging markets: Resilience and growth amid global turmoil", Brooking Institution Press.

LAEVEN L. and VALENCIA F., (2008): "Systemic banking crises: a new database", IMF Working Papers, no.08/224.

LAEVEN L. and VALENCIA F., (2010): "Resolution of Banking Crises: The Good, the Bad, and the Ugly" IMF Working Papers, no. 10/44.

LAEVEN L. and VALENCIA F., (2012): "Systemic banking crises database: An update" IMF Working Papers, no. 12/63.

LEVY-YEYATI E. and STURZENEGGER F., (2005): "Classifying exchange rate regimes: Deeds vs. words", European Economic Review 49(6), pp. 1603-1635.

LEVY-YEYATI E., STURZENEGGER F. and REGGIO I., (2010): "On the endogeneity of exchange rate regimes", European economic review, 54(5), pp. 659-677.

LIM C. H., COLUMBA F., COSTA A., KONGSAMUT P., OTANI A., SAIYID M., WEZEL T. and WU X., (2011): "Macroprudential policy: what instruments and how to use them? Lessons from country experiences", International Monetary Fund.

MAGUD N.E., REINHART C.M., and VESPERONI E.R., (2011) : "Capital inflows, Exchange rate flexibility, and Credit booms", NBER Working Paper, no.17670, December.

MENDOZA, E.G. and TERRONES, M.E., (2008) : "An anatomy of credit booms: evidence from macro aggregates and micro data.", NBER Working Paper, no.14049, May.

RAVN, Morten O. and UHLIG, Harald., (2002): "On adjusting the Hodrick-Prescott filter for the frequency of observations", Review of Economics and Statistics, 84(2), pp. 371-376.

REINHART C.M. et REINHART V.R. (2008) : "Capital flow bonanzas: An encompassing view of the past and present.", NBER Working Paper, no.14321, September.

REINHART C.M and ROGOFF K.S, (2004): "The Modern History of Exchange Rate Arrangements: A Reinterpretation", The Quarterly Journal of Economics, vol. 119, No. 1 (Feb., 2004), pp. 1-48.

REINHART C.M and ROGOFF K.S, (2010): "From financial crash to debt crisis", NBER Working Paper, no.15795, March.

TIRPÁK M. and ROSENBERG C.B., (2008): "Determinants of Foreign Currency Borrowing in the New Member States of the EU (EPub).", International Monetary Fund (Vol. 8).

TAYLOR M.P. and SARNO L., (1997) : "Capital flows to developing countries: long-and short-term determinants.", The World Bank Economic Review, 11(3), pp. 451-470. 


\section{Appendix}

Table .1 - Definition and Sources of variables used in Regression Analysis

\begin{tabular}{|c|c|}
\hline Variable & Definitions and Sources \\
\hline ERR & $\begin{array}{l}\text { de facto exchange rate regime coarse classification } \\
\text { Source: Ilzetzki, Reinhart and Rogoff, (2008) }\end{array}$ \\
\hline k_flow & $\begin{array}{l}\text { Non FDI net capital flow (millions USD) }{ }^{a} \\
\text { Source : Oxford Economics }\end{array}$ \\
\hline gdp & $\begin{array}{l}\text { Gross Domestic Product, current prices, (billions USD) } \\
\text { Source : World Economic Outlook (IMF, 2012) }\end{array}$ \\
\hline $\mathrm{k} / \mathrm{gdp}$ & Net capital flow to GDP ratio \\
\hline k_cyclecomp & Hodrick-Prescott cycle of net capital flow \\
\hline gdp_rate & $\begin{array}{l}\text { Annual percent change of constant price GDP } \\
\text { Source : World Economic Outlook (IMF, 2012) }\end{array}$ \\
\hline extdebt & $\begin{array}{l}\text { Total (public plus private) gross external debt/GDP } \\
\text { Source : Reinhart and Rogoff, (2010) }\end{array}$ \\
\hline $\mathrm{mm}$ _rate & $\begin{array}{l}\text { Money Market Rate (annual) })^{b} \\
\text { Source : International Financial Statistics (IMF, 2013) }\end{array}$ \\
\hline$\Delta \log$ Dom_cred & $\begin{array}{l}\text { Rate of growth of Domestic credit provided by banking sector ( } \% \text { of GDP) } \\
\text { Source: World Development Indicators (World Bank) }\end{array}$ \\
\hline trade & $\begin{array}{l}\text { Trade Openness : Exports }+ \text { Imports of goods and services ( } \% \text { of GDP) } \\
\text { Source : World Development Indicators (World Bank) }\end{array}$ \\
\hline fed_rate & $\begin{array}{l}\text { Fed Funds rate (annual) } \\
\text { Source : International Financial Statistics (IMF, 2013) }\end{array}$ \\
\hline fed_diff & Difference between Money Market Rate and Fed Funds Rate \\
\hline cpi_rate & $\begin{array}{l}\text { Inflation, average consumer prices rate of growth } \\
\text { Source: World Economic Outlook (IMF, 2012) }\end{array}$ \\
\hline kaopen & $\begin{array}{l}\text { Index measuring a country's degree of financial account openness } \\
\text { Source: Chinn and Ito, (2008) }\end{array}$ \\
\hline us_diff & $\begin{array}{l}\text { Difference between GDP growth rate and US GDP growth rate } \\
\text { Source: World Economic Outlook (IMF, 2012) }\end{array}$ \\
\hline flm & $\begin{array}{l}\text { Ratio of Foreign Liabilities to Money } \\
\text { International Financial Statistic (IMF, 2013) } \\
\text { line } 26 \text { C / (line } 14+\text { line } 24)\end{array}$ \\
\hline crisis & $\begin{array}{l}\text { Systemic banking, currency, and sovereign debt crises } \\
\text { Source: Laeven and Valencia, (2012) }\end{array}$ \\
\hline
\end{tabular}




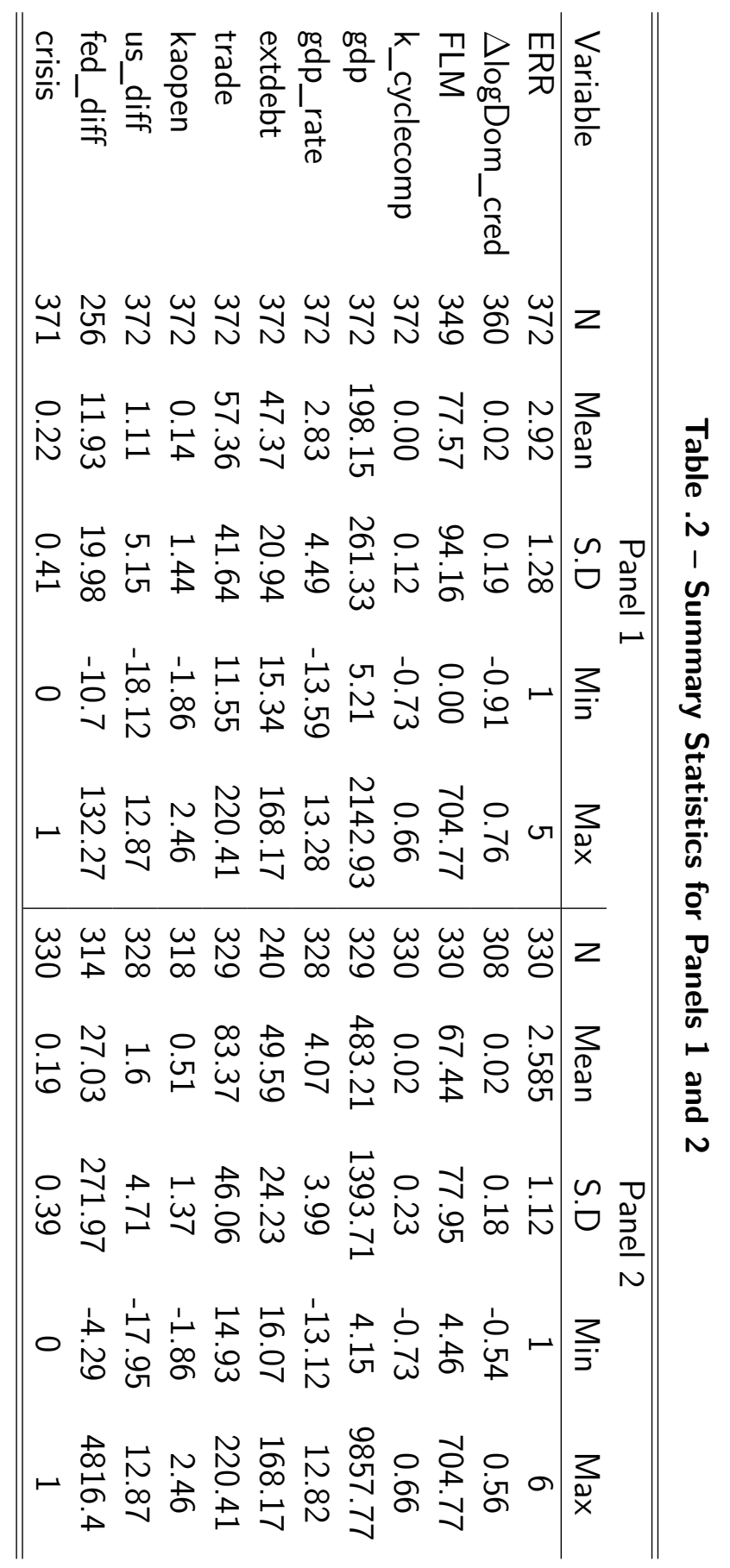


Figure .1 - Net Private Financial Flows to Emerging Market and Developing Economies (U.S. dollars)

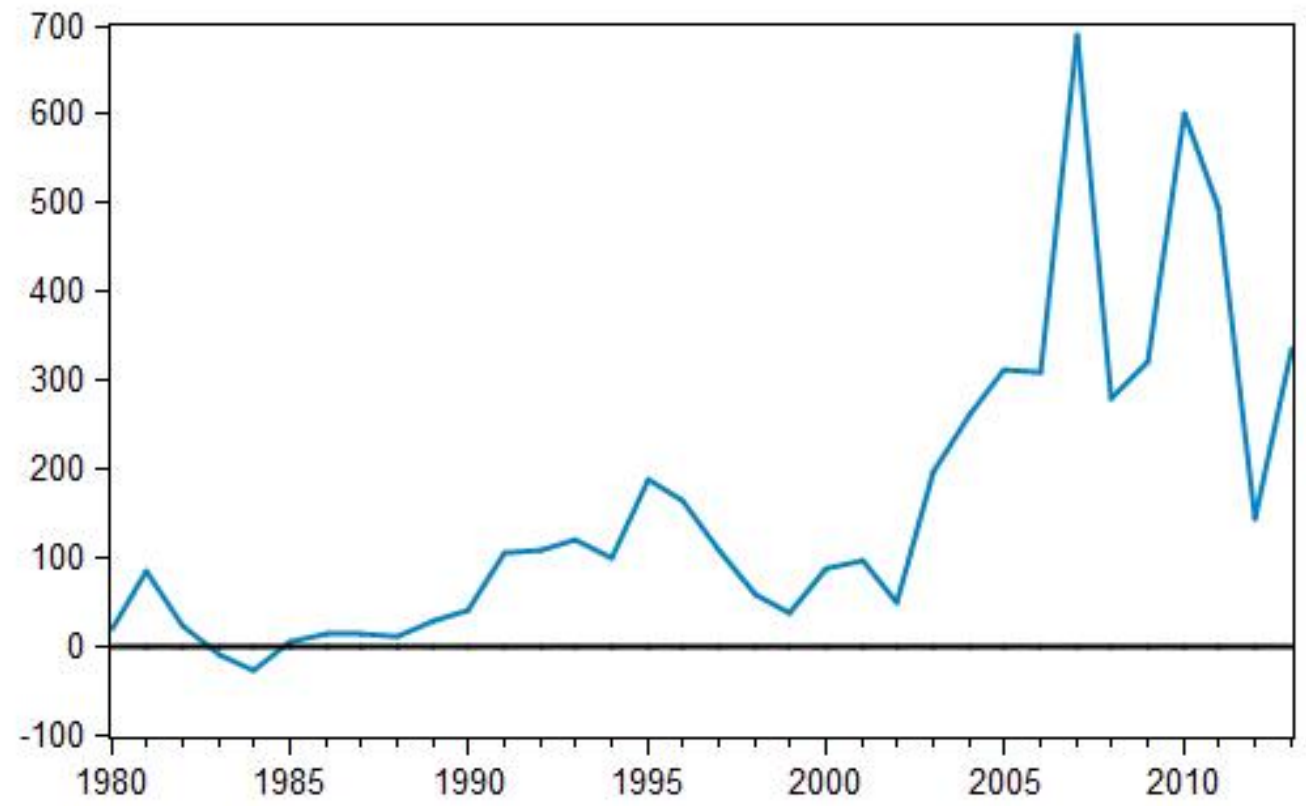

Source: World Economic Outlook (WEO) 2013

Table .3 - Estimation for pooled panel (dependent variable: cyclical component of capital flows)

\begin{tabular}{lccc|ccc}
\hline \hline variable & \multicolumn{3}{c}{ Panel 1 } & \multicolumn{3}{c}{ Panel 2 } \\
\hline C & -0.016 & 0.000 & 0.013 & $-0.158^{* *}$ & $-0.176^{* * *}$ & $-0.084^{*}$ \\
ERR & $(0.047)$ & $(0.038)$ & $(0.024)$ & $(0.072)$ & $(0.064)$ & $(0.044)$ \\
& -0.004 & 0.000 & 0.000 & 0.008 & 0.016 & 0.0196 \\
kaopen(-1) & $(0.007)$ & $(0.006)$ & $(0.05)$ & $(0.016)$ & $(0.013)$ & $(0.013)$ \\
& -0.003 & -0.004 & & $0.018^{*}$ & $0.018^{*}$ & $0.024^{* *}$ \\
trade(-1) & $(0.009)$ & $(0.006)$ & & $(0.011)$ & $(0.009)$ & $(0.009)$ \\
& 0.000 & 0.000 & & 0.000 & & \\
gdp_rate & $(0.000)$ & $(0.000)$ & & $(0.000)$ & & \\
& $0.012^{* * *}$ & $0.012^{* * *}$ & $0.011^{* * *}$ & 0.006 & $0.014^{* * *}$ & $0.013^{* * *}$ \\
US_diff & $(0.004)$ & $(0.002)$ & $(0.001)$ & $(0.008)$ & $(0.004)$ & $(0.003)$ \\
& -0.001 & & & 0.009 & & \\
external debt(-1) & $(0.004)$ & & & $(0.006)$ & & \\
& $-0.001^{* * *}$ & $-0.002^{* * *}$ & $-0.002^{* * *}$ & 0.000 & 0.000 & \\
fed_rate & $(0.000)$ & $(0.000)$ & $(0.000)$ & $(0.000)$ & $(0.000)$ & \\
& $0.006^{* *}$ & $0.004^{* *}$ & $0.003^{* *}$ & $0.023^{* * *}$ & $0.022^{* * *}$ & \\
fed_diff & $(0.002)$ & $(0.002)$ & $(0.002)$ & $(0.007)$ & $(0.007)$ & \\
& 0.000 & & & 0.000 & & \\
crisis & $(0.000)$ & & & $(0.000)$ & & -0.048 \\
& $-0.033^{*}$ & -0.019 & & $-0.084^{* *}$ & $-0.083^{* *}$ & $-0.037)$ \\
\hline Adjusted R-squared & $(0.019)$ & $(0.017)$ & & $(0.038)$ & $(0.037)$ & $(0.037)$ \\
Observations & 0.116 & 0.172 & 0.174 & 0.129 & 0.133 & 0.087 \\
\hline \hline
\end{tabular}

Numbers in brackets are standard errors

$* * *, * *, *$ indicate significance at 1,5 , and 10 percent levels, respectively. 
Table .4 - Alternative specifications with country/time effects and GLS weights (dependent variable: cyclical component of capital flows)

\begin{tabular}{|c|c|c|c|c|c|c|c|c|}
\hline \multirow{3}{*}{$\begin{array}{l}\text { variable } \\
\text { C }\end{array}$} & \multicolumn{4}{|c|}{ Panel 1} & \multicolumn{4}{|c|}{ Panel 2} \\
\hline & \multicolumn{2}{|c|}{ OLS } & \multicolumn{2}{|c|}{ GLS } & \multicolumn{2}{|c|}{ OLS } & \multicolumn{2}{|c|}{ GLS } \\
\hline & $\begin{array}{c}0.012 \\
(0.024)\end{array}$ & $\begin{array}{c}-0.016 \\
(0.016)\end{array}$ & $\begin{array}{c}0.011 \\
(0.019)\end{array}$ & $\begin{array}{c}0.003 \\
(0.014)\end{array}$ & $\begin{array}{c}0.080 \\
(0.104)\end{array}$ & $\begin{array}{l}-0.010 \\
(0.042)\end{array}$ & $\begin{array}{l}-0.061^{*} \\
(0.033)\end{array}$ & $\begin{array}{c}-0.032 \\
(0.025)\end{array}$ \\
\hline ERR & $\begin{array}{c}0.001 \\
(0.006)\end{array}$ & $\begin{array}{c}0.002 \\
(0.004)\end{array}$ & $\begin{array}{l}-0.000 \\
(0.004)\end{array}$ & $\begin{array}{c}0.000 \\
(0.003)\end{array}$ & $\begin{array}{l}0.030 * \\
(0.018)\end{array}$ & $\begin{array}{l}-0.03 \\
(0.011)\end{array}$ & $\begin{array}{l}-0.007 \\
(0.007)\end{array}$ & $\begin{array}{l}-0.002 \\
(0.006)\end{array}$ \\
\hline kaopen(-1) & & & & & $\begin{array}{c}0.075^{* * *} \\
(0.015)\end{array}$ & & & \\
\hline trade $(-1)$ & & & & & $\begin{array}{c}-0.003 * *^{b} \\
(0.001)\end{array}$ & & $\begin{array}{c}-0.002 *^{b} \\
(0.000)\end{array}$ & \\
\hline gdp_rate & $\begin{array}{c}0.011^{* * *} \\
(0.002)\end{array}$ & $\begin{array}{c}0.005^{* * *} \\
(0.001)\end{array}$ & $\begin{array}{c}0.009 * * * \\
(0.001)\end{array}$ & $\begin{array}{c}0.016 * * * \\
(0.003)\end{array}$ & & & $\begin{array}{c}0.013^{* * *} \\
(0.002)\end{array}$ & $\begin{array}{c}0.003 *^{a} \\
(0.002)\end{array}$ \\
\hline US_diff & & & & $\begin{array}{c}0.006^{* * *} \\
(0.000)\end{array}$ & $\begin{array}{r}0.006 *^{a} \\
(0.003)\end{array}$ & & & $\begin{array}{c}0.010^{* * *} \\
(0.002)\end{array}$ \\
\hline external debt(-1) & $\begin{array}{c}-0.002^{* * *} \\
(0.000)\end{array}$ & & $\begin{array}{c}-0.001 * * * \\
(0.000)\end{array}$ & $\begin{array}{c}0.001 * * * \\
(0.000)\end{array}$ & & $\begin{array}{c}0.001^{* *} \\
(0.000)\end{array}$ & & \\
\hline fed_rate & $\begin{array}{l}0.004^{* *} \\
(0.001)\end{array}$ & & $\begin{array}{l}0.003^{*} \\
(0.001)\end{array}$ & $\begin{array}{c}0.004^{* * *} \\
(0.001)\end{array}$ & & & $\begin{array}{c}0.018^{* * *} \\
(0.004)\end{array}$ & $\begin{array}{c}0.015^{* * *} \\
(0.004)\end{array}$ \\
\hline fed_diff & & & & & & & & \\
\hline crisis & $\begin{array}{l}-0.018^{*} \\
(0.009)\end{array}$ & $\begin{array}{c}-0.044 * * * \\
(0.014)\end{array}$ & & & & $\begin{array}{c}-0.102 * * * \\
(0.031)\end{array}$ & $\begin{array}{c}-0.093 * * * \\
(0.017)\end{array}$ & $\begin{array}{c}-0.048^{* *} \\
(0.019)\end{array}$ \\
\hline Fixed Effects & Yes & No & No & No & Yes & No & No & No \\
\hline Time Effects & No & Yes & No & No & No & Yes & No & No \\
\hline Cross-Section Weights & No & No & Yes & No & No & No & Yes & No \\
\hline Period Weights & No & No & No & Yes & No & No & No & Yes \\
\hline Adjusted R-squared & 0.17 & 0.42 & 0.19 & 0.18 & 0.10 & 0.35 & 0.33 & 0.26 \\
\hline Observations & 359 & 371 & 360 & 360 & 296 & 224 & 327 & 306 \\
\hline
\end{tabular}

Numbers in brackets are standard errors

$* * *, * *, *$ indicate significance at 1,5 , and 10 percent levels, respectively.

a : Lagged value of the variable

b : Current value of the variable 